\title{
Bioclimatic effects on different mountain birch populations in Fennoscandia
}

\author{
Oddvar Skre ${ }^{1, *}$, Bogdan Wertz ${ }^{2}$, Frans E. Wielgolaski ${ }^{3}$, Paulina Szydlowska ${ }^{2}$, \\ Stein-Rune Karlsen ${ }^{4}$ \\ ${ }^{1}$ Skre Nature and Environment, Fanaflaten 4, 5244 Fana, Norway \\ ${ }^{2}$ University of Agriculture in Krakow, Dept. of Biometry and Forest Productivity, Al. 29 Listopada 46, 31-425 Krakow, Poland \\ ${ }^{3}$ Department of Bioscience, University of Oslo, PO Box 1066 Blindern, 0316 Oslo, Norway \\ ${ }^{4}$ NORUT Northern Research Institute, PO Box 6434, 9294 Tromsø, Norway
}

\begin{abstract}
Mountain birch Betula pubescens ssp. tortuosa is the main treeline species in northern Europe, and the recent increase in treeline elevation in Fennoscandia due to climate change and land use has made mountain birch an important bioindicator. Birch seedlings from 10 populations were therefore transplanted to 3 northern Fennoscandian sites $(1$ oceanic, 1 continental mountain and 1 Arctic coastal site). Annual measurements were carried out on growth parameters and phenology (date of budbreak) from 1992 onwards. At the coastal site, measurements covered the whole period 1993 to 2010, while at the 2 other sites measurements covered only the period 1993 to 1997 (mountain site) and 2010 to 2014 (both sites). During the last period (2010 to 2014), measurements were made on a new set of seedlings, transplanted in 2002. The plants suffered a temporary transplantation stress because of root damage. In general, budburst occurred earlier in populations from northern and continental sites than from southern and coastal sites. Survival rates were dependent on climate and were generally higher at the oceanic than at the mountain site, due to more autumn frost and insect damage at the latter. At the mountain site, survival rates were lowest in oceanic and southern populations; at the Arctic site, survival rates were lowest in continental populations; while at the oceanic site, only small differences were found between populations. The present results seem to indicate that climate is an important driver of change at the mountain birch treeline, although land-use changes may be more important in the short term. In the future, when a warmer climate is predicted, plants that are adapted to a coastal climate may expand their range, and increased winter temperatures are expected to favour insect-resistant polycormic birch inbreeding with dwarf birch Betula nana.
\end{abstract}

KEY WORDS: Treelines $\cdot$ Climate change $\cdot$ Survival $\cdot$ Height and diameter growth $\cdot$ Dieback

\section{INTRODUCTION}

The circumpolar treeline between the northern boreal forest and the treeless tundra is one of the main vegetation transition zones in the Northern Hemisphere. The high sensitivity of mountain forests to climate and land-use changes (e.g. Callaghan et al. 2013, Holtmeier 2007) makes the circumpolar treeline a good indicator of these changes. In contrast to most of the circumpolar area, mountain birch Betula pubescens ssp. tortuosa is the main treeline species in

${ }^{*}$ Corresponding author: oddvar@nmvskre.no

${ }^{\S}$ Advance View was available online June 28, 2017
Fennoscandia. Although the high-elevation forest limits have been lowered by past intensive land use (Bryn \& Daugstad 2001, Gehrig-Fasel et al. 2007), these forests are mainly influenced by climate (Körner $\&$ Paulsen 2004). Consequently, reduced land-use intensity combined with climatic warming would lead to increased forest cover and treeline elevation, while intensive or sustained land use would oppose the climatic effect (Bryn 2008, Aune et al. 2011). Mountain forests may be further influenced by seed production and quality, and soil conditions (Speed et al. 2011).

() The authors 2017. Open Access under Creative Commons by Attribution Licence. Use, distribution and reproduction are unrestricted. Authors and original publication must be credited.

Publisher: Inter-Research · www.int-res.com 
At a large scale, the Arctic treeline seems to be mainly a result of the 'climate hazard' factor (e.g. Skre et al. 2002, Sveinbjörnsson et al. 2002), including seed reproduction and freezing stress. However, individual clones of trees may survive as vegetative individuals, and eventually produce viable seeds as soon as summer temperatures are high enough for seed reproduction (Kullman 1998, Payette et al. 2002). Other studies such as Karlsson \& Nordell (1996) and Weih \& Karlsson (1999) indicate that the uptake of nitrogen from soil is probably the most important limiting process for growth of $B$. pubescens at the treeline in northern Fennoscandia. In addition, the transition from open, treeless tundra to boreal forests implies increased carbon sequestration, but also increased $\mathrm{CO}_{2}$ output because of decreased albedo, particularly in evergreen tree species like spruce and pine (e.g. de Wit et al. 2014).

Global warming may influence tree growth and treeline position through increased seed viability and production, as well as increased vegetative growth. The first indication of these changes is therefore often an increase in seedling density at or above the treeline, as observed by Juntunen \& Neuvonen (2006) in northern Finland. The final outcome is dependent on these factors and on the degree of human interaction or other disturbance factors. Vitasse et al. (2014a) found that winter warming would increase the risk of premature dehardening and eventual spring frost damage. Plants and ecotypes of $B$. pubescens with high demands for dormancy breaking would have an advantage (e.g. Heide 1993). As a rule, B. pubescens needs a chilling period below $10^{\circ} \mathrm{C}$ for budbreak. This requirement is expected to decrease with increasing latitudes of their mother trees (Myking \& Heide 1995) and to increase with increasing oceanity (Leinonen 1996, Myking 1999). Similar results were found earlier by Larsen (1976) in Douglas fir Pseudotsuga menziesii provenances from British Columbia. According to Myking \& Heide (1995), there is little risk of chilling deficit in birch in Scandinavia, even with a climatic warming of 7 to $8^{\circ} \mathrm{C}$ in winter. Seedlings and young trees are generally more susceptible to spring frosts than adult trees because of earlier budbreak (Vitasse et al. 2014b)

Grazing by sheep and reindeer has formed the treeline as well as the forest line in northern Norway (Tømmervik et al. 2004, Dalen \& Hofgaard 2005), and mammals or insects may have modifying effects on treelines in a variety of environments (e.g. Cairns et al. 2007). Wind may also be an important factor locally (Scott et al. 1993, Sveinbjörnsson et al. 2002).
However, Speed et al. (2011) concluded that sheep grazing would usually dominate over climatic warming, dependent on the intensity of grazing. In connection, according to e.g. Anamthawat-Jonsson et al. (1993), dwarf birch Betula nana may be more resistant to sheep grazing than mountain birch B. pubescens, which may have some influence on the competition between these 2 species. Similar relationships may also be found regarding birch resistance against insect attacks (e.g. Haukioja et al. 1988, Neuvonen et al. 2005).

Insect herbivory that causes tree death is the most widely reported mode of animal activity, and the effect of the autumnal moth Epirrita autumnata on $B$. pubescens has been widely studied in northern Sweden and Finland. Tenow et al. (2005) found that Epirrita eggs would not survive winter temperatures below $-35^{\circ} \mathrm{C}$, hence global warming would increase their survival rates. They also found that polycormic birch would recover faster than monocormic birch after insect attacks, due to higher ability to form lateral shoots. According to Wielgolaski (2005), polycormic birch is partly a result of inbreeding with $B$. nana in the B. pubescens populations (cf. Nilsen \& Wielgolaski 2001, Thórsson et al. 2001). As climatic warming is expected to favour more insect outbreaks, future warming would lead to more polycormic birch that will recover faster and restore the carbon reserves (Karlsson \& Weih 2003). According to Jepsen et al. (2008) and Jepsen et al. (2013), who used MODIS-NDVI (moderate resolution imaging spectroradiometer normalized difference vegetation index) data to monitor the spatio-temporal dynamics of moth outbreaks in birch forests (Jepsen et al. 2009), the winter moth Operophtera brumata is more common along the coast of northern Norway than the autumnal moth, but has recently expanded into colder areas due to the change in climate. The total impact of defoliation on the birch populations is therefore expected to increase in the future, and with increasing frequency and more species involved, resistance to insect attacks is expected to be an increasingly important selective factor for survival and growth at the treeline.

Also, summer temperatures influence birch growth by improving foliage quality and the capacity of trees to recover from grazing and/or insect attacks (Neuvonen et al. 1999, Virtanen \& Neuvonen 1999).

The aim of the present study was to determine the differences in survival rates and in phenological and growth responses in young plants from different provenances of mountain birch B. pubescens ssp. tortuosa transplanted to 3 sites with varying environ- 
mental conditions, and compare the results with earlier findings (e.g. Ovaska et al. 2005). The results from the present study are expected to give some indications about how future climatic changes may influence survival and growth of mountain birch, and will be used in an attempt to answer the following questions: (1) How do birch provenances respond to climatic stress? (2) How well adapted are birch provenances to the expected climate change? (3) What are the implications of (1) and (2) for the future?

The present study was designed to test abiotic stress, but as insect attacks are closely connected to climatic warming, these damages are included in the analysis, whereas land-use changes such as overgrazing or land abandonment (Callaghan et al. 2013) were prevented by fencing the birch gardens. On the other hand, reindeer overgrazing in Finland has been shown to prevent birch regeneration after insect attacks (Lehtonen \& Heikkinen 1995) that may be favoured by global warming.

\section{MATERIALS AND METHODS}

\subsection{Experimental design}

Seedlings of mountain birch Betula pubescens var. tortuosa from southern and northern, as well as oceanic and more continental origin, and various ele- vations were transferred to 3 different transplant gardens north of the Arctic Circle in Fennoscandia. The transplant gardens were situated along an oceanitycontinentality gradient and at different elevations (Fig. 1, Table 1). Of the established sites, 2 (Kilpisjärvi and Vardø) were situated close to the Arctic or alpine treelines, while the third (Melbu) was situated at an elevation about $50 \mathrm{~m}$ lower than the treeline.

The 10 seed populations from 5 different countries used in the present study (Table 1) were sown in 1991 in Pakatti nursery, Finland, and transplanted to the 3 gardens in 1992. In Table 2, the position and elevations of the seed populations are shown with the mean January $\left(t_{1}\right)$ and July temperatures $\left(t_{7} ;{ }^{\circ} \mathrm{C}\right)$. The continentality is determined mainly by the amplitude between $t_{1}$ and $t_{7}$ (Ovaska et al. 2005). As a result, populations from Utsjoki (FU), Kevo (FJ and FK), Kilpisjärvi (FKi) and Abisko (SAb) were classified as continental, and those from Narsassuaq (GNa), Hafnarskogur (IHa), Melbu (NMe) and Hammerfest (NHa) as oceanic, while the Blefjell population $(\mathrm{NBl})$ was intermediate between continental and oceanic (cf. Fig. 1).

A total of 6 replicates, each with 25 plants per population, were established at each garden. The sites were fenced to prevent reindeer, sheep or cattle grazing, on $1 \mathrm{~m}^{2}$ plots per plant. Survival rates during the period after transplantation (cf. Fig. 2), measurements of total and living height, stem base diameter,

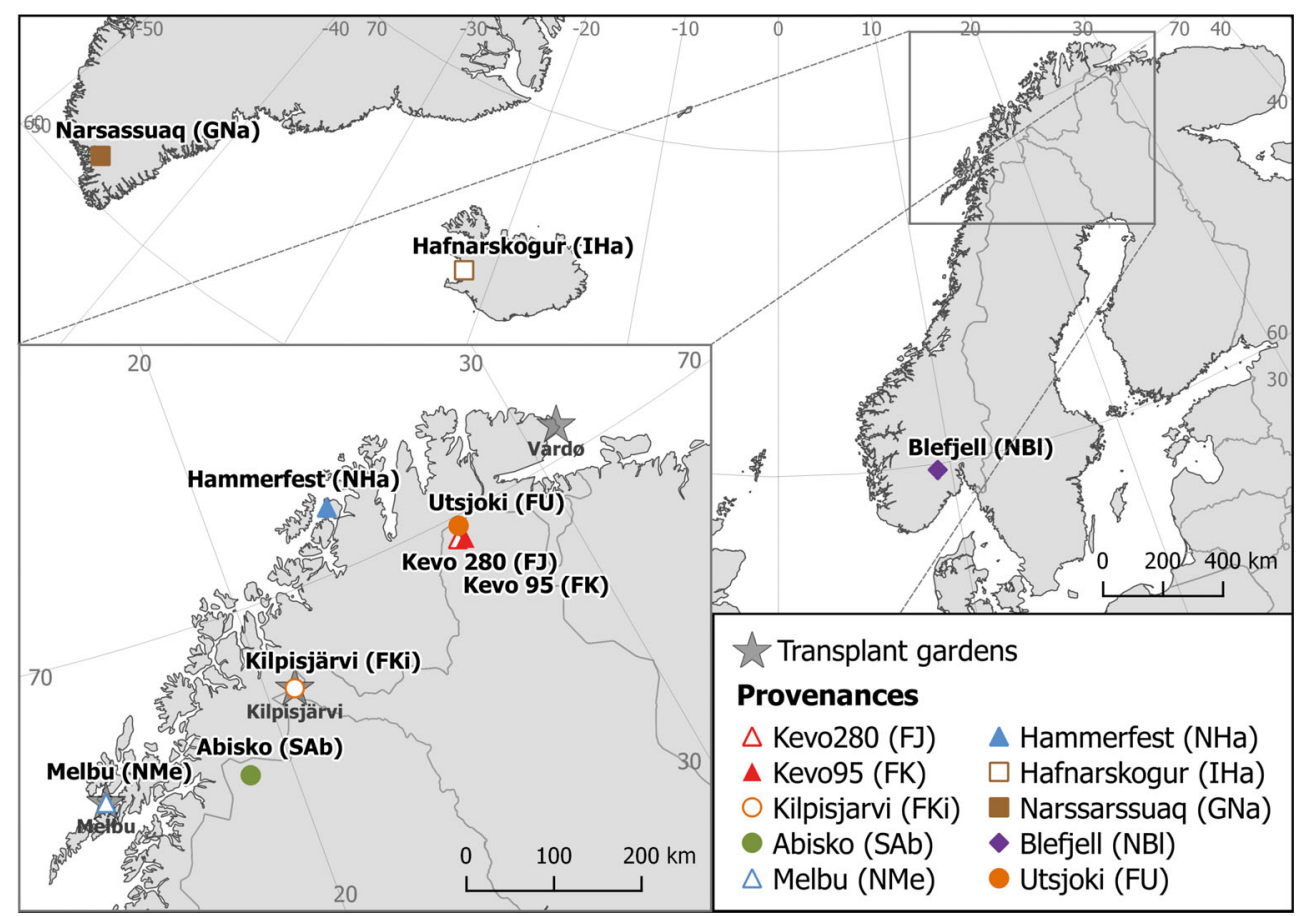

Fig. 1. Populations and transplant garden sites 
Table 1. Origin of seed populations, with position, elevation (Elev.), mean temperatures 1961 to $1990\left({ }^{\circ} \mathrm{C}\right)$ of January $\left(t_{1}\right)$ and July $\left(t_{7}\right)$, and dates of budbreak (1994). The localities are classified as oceanic when the difference between mean July and January temperatures ( $t_{7}$ and $t_{1}$, respectively) is below $20^{\circ} \mathrm{C}$

\begin{tabular}{|c|c|c|c|c|c|c|c|c|c|}
\hline \multirow[t]{2}{*}{ No. } & \multirow[t]{2}{*}{ Population } & \multirow[t]{2}{*}{ Continentality } & \multirow{2}{*}{$\begin{array}{c}\text { Elev. } \\
\text { (m a.s.l.) }\end{array}$} & \multirow[t]{2}{*}{${ }^{\circ} \mathrm{N}$} & \multirow[t]{2}{*}{${ }^{\circ} \mathrm{E}$} & \multirow[t]{2}{*}{$t_{1}$} & \multirow[t]{2}{*}{$t_{7}$} & \multicolumn{2}{|c|}{ Budbreak date } \\
\hline & & & & & & & & Kilpisjärvi & Melbu \\
\hline 1 & Kevo280 (FJ) & Continental & 280 & 69.8 & 27.0 & -12.1 & 11.8 & 23 June & 20 May \\
\hline 2 & Kevo95 (FK) & Continental & 95 & 69.8 & 27.0 & -13.6 & 13.3 & 23 June & 20 May \\
\hline 3 & Kilpisjärvi (FKi) & Continental & 500 & 69.0 & 20.8 & -10.6 & 11.2 & 19 June & 19 May \\
\hline 4 & Abisko (SAb) & Continental & 360 & 68.3 & 18.8 & -10.3 & 11.4 & 20 June & 19 May \\
\hline 5 & Melbu (NMe) & Oceanic & 40 & 68.5 & 14.8 & -1.0 & 13.1 & 13 July & 21 May \\
\hline 6 & Hammerfest (NHa) & Oceanic & 70 & 70.7 & 23.7 & -5.5 & 12.3 & 18 June & 17 May \\
\hline 7 & Hafnarskogur (IHa) & Oceanic & 20 & 64.5 & -21.9 & -0.3 & 10.2 & 13 July & 22 May \\
\hline 8 & Narsassuaq (GNa) & Oceanic & 70 & 61.2 & -45.4 & -3.3 & 7.0 & 17 July & 20 May \\
\hline 9 & Blefjell (NBl) & Intermediate & 750 & 59.8 & 9.2 & -5.6 & 13.4 & 20 July & 23 May \\
\hline 10 & Utsjoki (FU) & Continental & 200 & 69.9 & 27.0 & -12.8 & 12.5 & 22 June & 19 May \\
\hline
\end{tabular}

Table 2. Site characteristics of the transplant gardens, showing elevation (Elev. $\mathrm{m}$ a.s.l.), position, normal mean temperatures $1961-1990\left({ }^{\circ} \mathrm{C}\right)$ of January $\left(t_{1}\right)$ and July $\left(t_{7}\right)$, annual precipitation $(P, \mathrm{~mm})$, and number of days with snow cover (SD) and mean freezing temperatures $(<0)$

\begin{tabular}{|lrrrrrrrr|}
\hline Site & Elev. & ${ }^{\circ} \mathrm{N}$ & ${ }^{\circ} \mathrm{E}$ & $t_{1}{ }^{\mathrm{a}}$ & $t_{7}{ }^{\mathrm{a}}$ & $P$ & $\mathrm{SD}$ & $<0$ \\
\hline Vardø (Arctic oceanic) & 13 & 70.3 & 31.1 & -4.3 & 9.1 & 509 & 169 & 190 \\
Kilpisjärvi (alpine continental) & 500 & 69.0 & 20.8 & -10.6 & 11.2 & 525 & 195 & 234 \\
Melbu (oceanic) & 40 & 68.5 & 14.8 & -1.0 & 13.1 & 782 & 118 & 114 \\
a Climate of seed populations and birch gardens is measured at nearby mete- \\
$\begin{array}{l}\text { orological stations, except Kevo280, which is extrapolated from Kevo95 by } \\
\text { elevation difference }\end{array}$
\end{tabular}

and phenology (date of budbreak) were calculated annually during the period 1994 to 2010. However, many plants at the Vardø and Kilpisjärvi sites died during the first years after the transplantation due to frost and insect damage (R. Partanen pers. comm.). Owing to the strong decrease in survival rates at Kilpisjärvi, no observations were made after 1997 (Figs. 3, 4 \& 5), except from the control measurement in 2010. At Vardø, the observations were also too few to arrive at any conclusions, while at Melbu, the observations continued annually until 2010.

Owing to low survival rates in the first set of plants (henceforth 'old plants') from 1992, a new set of plants from 8 of the same populations (cf. Table 1) were raised in the greenhouse at the University of Tromsø and transplanted to the Vardø and Kilpisjärvi sites, with 20 plants per population and replicate. Population \#1 and 10 were omitted because of limited supply of viable seeds, and because preliminary measurements from Melbu and Kilpisjärvi indicated that they were not significantly different from population \#2 (Kevo95) (cf. Figs. 3, 4 \& 5). At the Vardø site, preliminary tests (O. Skre unpubl.) indicated that the results from 4 of the 5 replicates (I to IV) were vival rates $(\%)$, and total and living height and diameter measurements were calculated annually. Owing to the strong correlation between height and diameter growth (Table 3), only the height is included (see the Appendix).

Table 3. Pearson's correlation coefficients between variables, where SR is survival rate (\%) at plant level, $D_{\mathrm{AV}}$ is average stem base diameter $(\mathrm{mm})$ and $H_{\mathrm{AV}}$ is average total height (cm). Significance - light grey: significant at $\alpha=0.05$; dark grey: significant at $\alpha=0.01$

\begin{tabular}{|lccccc|}
\hline Garden & Generation & Variable & SR & $D_{\mathrm{AV}}$ & $H_{\mathrm{AV}}$ \\
\hline Melbu & Old & $\mathrm{SR}$ & & 0.50 & 0.46 \\
Melbu & Old & $D_{\mathrm{AV}}$ & 0.50 & & 0.93 \\
Melbu & Old & $H_{\mathrm{AV}}$ & 0.46 & 0.93 & \\
Kilpisjärvi & Old & $\mathrm{SR}$ & & 0.81 & 0.84 \\
Kilpisjärvi & Old & $D_{\mathrm{AV}}$ & 0.81 & & 0.88 \\
Kilpisjärvi & Old & $H_{\mathrm{AV}}$ & 0.84 & 0.88 & \\
Kilpisjärvi & New & $\mathrm{SR}$ & & 0.71 & 0.74 \\
Kilpisjärvi & New & $D_{\mathrm{AV}}$ & 0.71 & & 0.80 \\
Kilpisjärvi & New & $H_{\mathrm{AV}}$ & 0.74 & 0.80 & \\
Vardø & New & $\mathrm{SR}$ & & 0.20 & 0.24 \\
Vardø & New & $D_{\mathrm{AV}}$ & 0.20 & & 0.64 \\
Vardø & New & $H_{\mathrm{AV}}$ & 0.24 & 0.64 & \\
\hline
\end{tabular}




\subsection{Statistical analysis}

The datasets from old plants at Melbu 1994 to 2009, from Kilpisjärvi 1994 to 1997 and 2010, and from new plants at Kilpisjärvi and Vardø 2010 to 2014 were analysed. For evaluation of the bioecological success of each provenance and for their comparison, the following indicators were selected and computed from all years observed: (1) the survival rate (SR) at replicate level as a percentage of the total numbers of living plants during the observed years; (2) diameter $(D)$ measured for each living plant at the stem base; and (3) living height $(H)$ measured as the height of the longest living stem.

Preliminary measurements revealed quite frequent negative height increment (dieback) due to frost or insect damage, and sometimes also negative diameter growth (when a plant formed new stems after the death of old stems that had died or been destroyed). However, after careful initial data analysis (IDA), including detection of possible errors and influencing outliers, and inspection of variables' distributions and transformation attempts, we decided to provide comparison on the basis of quantitative analysis, using a linear-mixed model approach. Although some minor violations of its assumptions, such as deviations from normality (checked by Shapiro-Wilks test, at $\alpha=$ 0.05 ) and heterogeneity of variance (checked by Levene's test, at $\alpha=0.05$ ), were still present in the dataset, the applied method was found to be the best solution for processing the data, because it takes into account dependence of measurements (3 levels of nesting). Further, it can provide reliable results even with the missing data, and it provides quantitative estimators (parameters) that are easy to interpret, and their statistical significance can be assessed (B. Wertz unpubl.).

All provenances were characterised by the mean value of each indicator as well as $95 \%$ mean CI. For the analysis of temporal differences among tested provenances, the mean values in each year of observation in the old dataset were calculated and interconnected by lines, while the overall mean survival rates and total height were tested in the new dataset. For testing the relationships between selected indicators, the Pearson's correlation coefficient and its significance at $\alpha=0.05$ was calculated. To estimate the differences between provenances, the linear mixed-model approach was applied separately to each garden. The indicators describing the biological success $(\mathrm{SR}, D$ and $H$ ) were treated as dependent variables, while time (Year of life-numerical variable) and origin (Provenance - categorical variable) were treated as fixed factors. The random factor consisted of particular plants, nested within replicates and provenances. The constructed model allowed a different slope for each plant, and included both independent variables (time and origin) because they had the lowest values of Akaike's information criterion (AIC). All statistical analysis was performed in the $\mathrm{R}$ environment ( $\mathrm{R}$ Core Team 2015) with the help of the following packages: lme4 (Bates et al. 2015), enabling access to the creation of mixed models; lmerTest (Kuznetsova et al. 2016), providing pvalue calculations that are helpful for an assessment of the statistical significance of differences; sjPlot (Lüdecke 2016) for visualization of results; and AICCmodavg (Marc \& Mazerolle 2016), calculating AIC, suitable for optimal model selection.

\section{RESULTS AND DISCUSSION}

\subsection{Phenology}

The mean dates of budbreak in Table 1 varied from one year to another, according to winter temperatures and snow cover, but 1994 is chosen as representative because no temporal variations were found in the relationships between populations during the sample period (O. Skre unpubl.).

In 1994, budburst was almost 1 mo later in the southern and oceanic populations (NB, NMe, GNa and IHa) compared to the northern and continental populations (NHa, FKi, FK, FJ, SAb and FU), when transplanted to the continental Kilpisjärvi site (Table 1). According to Myking \& Heide (1995), this means that the thermal requirements for dormancy breaking are higher in the former than in the latter group. This is most obvious when comparing the oceanic NMe plants with the continental SAb and FKi populations originating from approximately the same latitude. According to Myking (1999) and Larsen (1976), oceanic populations need to be more resistant against occasional spring frosts than continental relatives, because of the slower transition between winter and summer temperatures in oceanic areas. On the other hand, foliar senescence is almost solely dependent on day length and elevation (Ovaska et al. 2005).

\subsection{Growth and survival rates}

Many plants at the Vardø and Kilpisjärvi sites died during the first years after the transplantation, due to climatic stress and insect damage (R. Partanen pers. 
comm.). Because of the strong decrease in survival rates at Kilpisjärvi, no observations were made after 1997, except from the control measurement in 2010. At Vardø, the observations were also too few to arrive at any conclusions, while at Melbu the observations continued annually until 2010. A much more rapid decrease in survival rates during the first years after transplantation (1994 to 1997) was detected at Kilpisjärvi than at Melbu (cf. Fig. 3). The main reason is probably that the Melbu site was located close to the sea and about $50 \mathrm{~m}$ below the treeline, with a much longer snow-free period (cf. Tables $1 \& 2$ ), and therefore was more protected from climatic damage than the site at Kilpisjärvi, which was located just below the treeline. The differences between sites (Fig. 2a,b) were strongest in the 4 southern and oceanic provenances (NMe, IHa, GNa and NBl). This result is in accordance with the basic assumption that the birch population has developed climatic adaptations to its different habitats that influence survival rates after transplantation (cf. Myking \& Heide 1995, Gamache \& Payette 2005). At the 3 most oceanic and southernmost sites (NB, GNa and $\mathrm{IH}$ ), only a few plants had survived by the end of the period at Kilpisjärvi (Fig. 3), and consequently the estimates of growth parameters, particularly the total height, dropped to almost zero (Table 4, Fig. 2).

There was a strong correlation between the survival rates of individual plants and the corresponding growth parameters in the old datasets (Melbu and Kilpisjärvi), and in the new dataset from Kilpisjärvi (Table 3). The implication is that plants that are already damaged by frost and/or insect attacks have a lower chance of survival than healthy plants.

The plants growing at the Kilpisjärvi site varied substantially and were less successful in terms of survival rates than the Melbu plants (Fig. 2). This difference can possibly be explained by more severe winters (Tables $1 \& 2$ ) and more frequent insect attacks (R. Partanen pers. comm.) at the Kilpisjärvi site, leading to more frequent dieback (cf. Tenow et al. 2005) and strong variation in living height (Fig. 5). The 3 southern populations ( $\mathrm{NBl}, \mathrm{GNa}$ and $\mathrm{IHa}$ ) and partly the northern oceanic NMe population seemed to be less successful than the northern continental populations, with Abisko (SAb) as an exception (cf. Fig. 2).

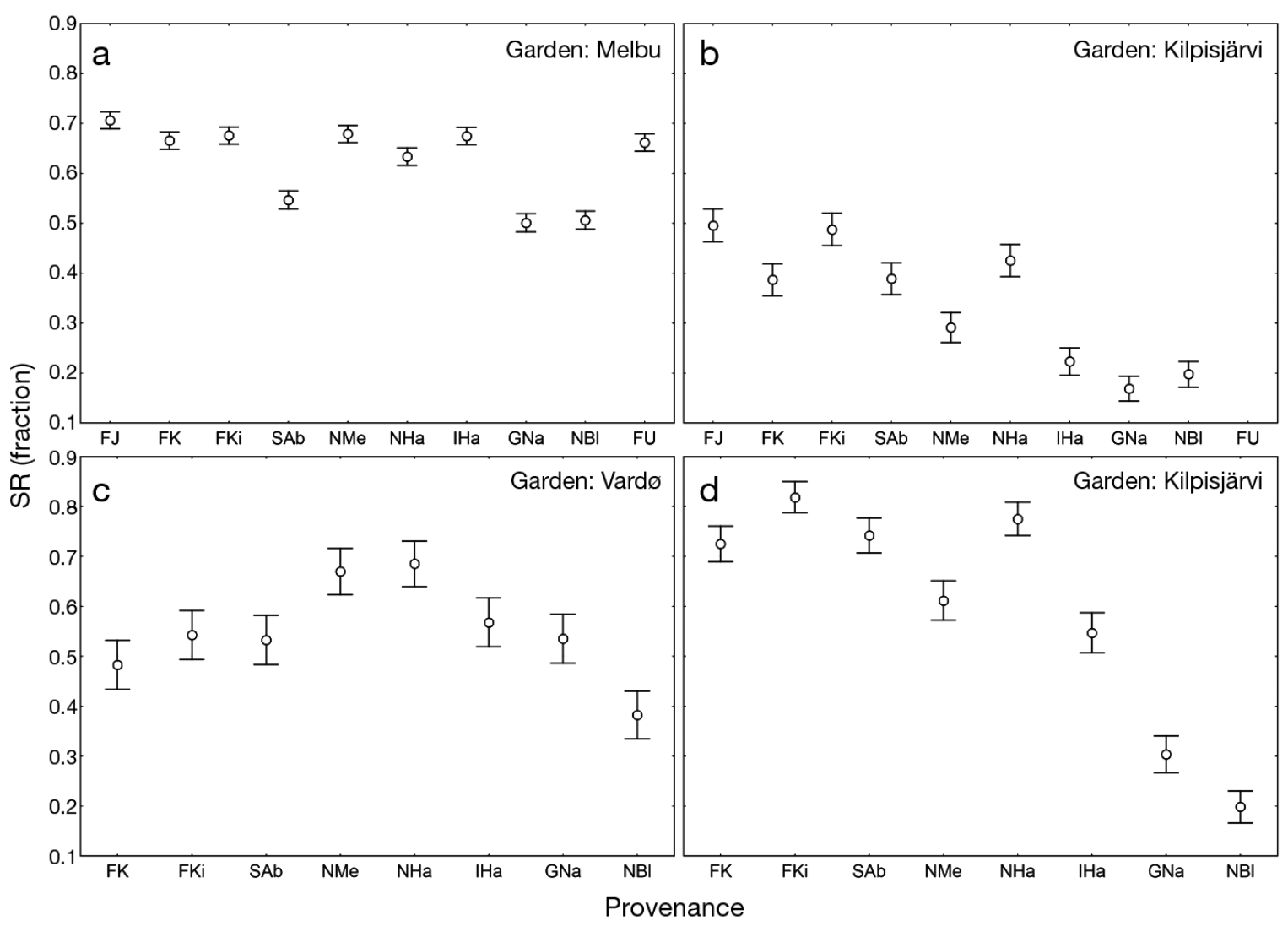

Fig. 2. Mean values of selected indicators, i.e. survival rates (SR, as fractions), with corresponding $95 \%$ CI for tested provenances of $(\mathrm{a}, \mathrm{b})$ old generation and $(\mathrm{c}, \mathrm{d})$ new generation plants at (a) Melbu, (b,d) Kilpisjärvi and (c) Vardø. See the Appendix for total height growth 


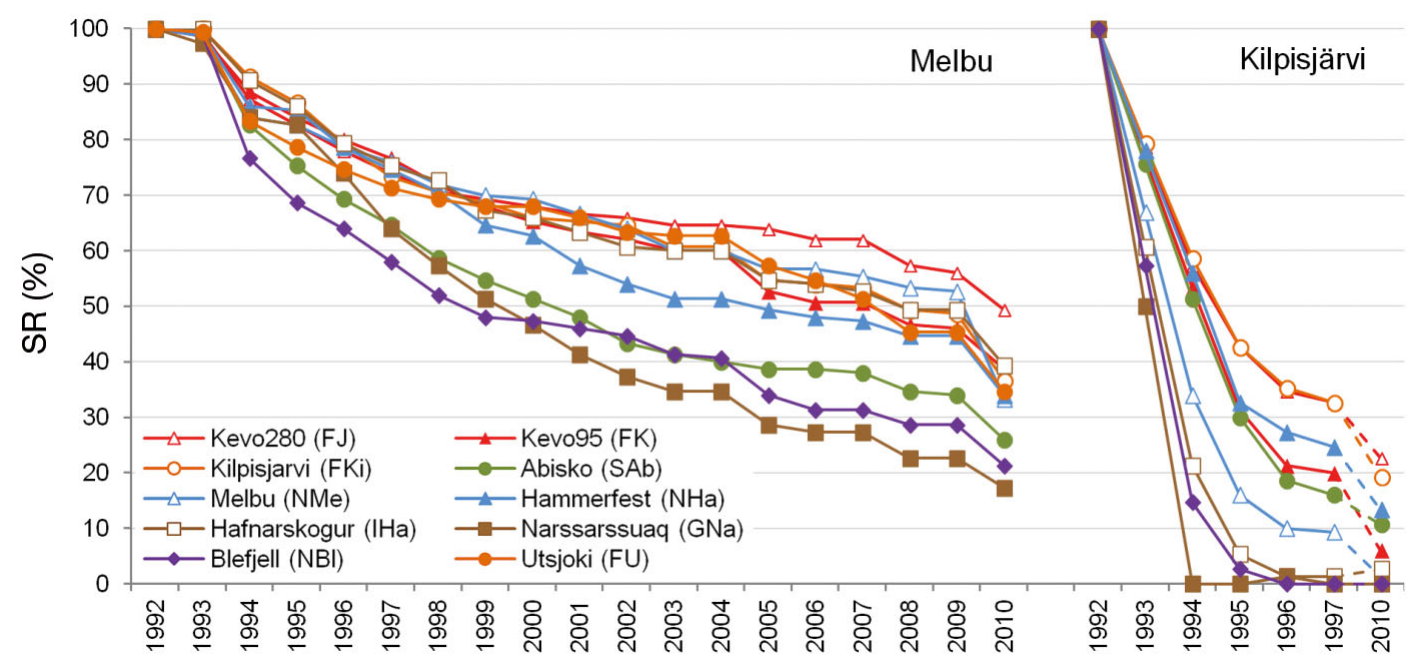

Fig. 3. Survival rates (SR) for tested provenances of old generations at Melbu (left) and Kilpisjärvi (right) as a function of time since 1992

The results of the linear mixed-model method (Table 4) agreed well with the conclusions from Fig. 2, i.e. there were significant differences between the survival rates in plants from Kevo and Kilpisjärvi (FJ, FK and FKi), and the western and southern plants (NBl and $\mathrm{GNa}$ ) at both sites. However, at Kilpisjärvi the survival rates of northern coastal plants (IHa and NMe) were also different from those from northern Finland. Similar patterns were also found when comparing stem diameter (B. Wertz unpubl.) and total height (Fig. A1 in the Appendix). The implication is that when southern and oceanic ecotypes are moved northward and inland, they continue growing late into the autumn and are easily subjected to frost damages (cf. Heide 1993, Myking \& Heide 1995). On the other hand, when northern ecotypes like NHa are moved southward, they start growing earlier in spring (cf. Table 1) and are protected from autumn frost by their early growth cessation (cf. Heide 1993, Taulavuori et al. 2004, Skre et al. 2008). They are also often characterized by so-called metabolic compensation as a response to low temperatures to compensate for a short growing season (Billings et al. 1971). This may be the main reason why the northern coastal Hammerfest population (NHa) showed the highest growth rates in terms of diameter and height growth (Figs. 4 \& 5) among populations. Hence, the northern coastal/oceanic NHa population was among the most successful, presumably because it is protected from late autumn frosts by its northern origin and from spring frosts by adaptation to a coastal climate (cf. Larsen 1976, Myking \& Heide 1995). The high stem growth in the NHa population may also partly be explained by the strong monocormic growth pattern in this population (H. Tømmervik pers. comm.).

Figs. 4 \& 5 show a relatively long recovery time ( 7 to $8 \mathrm{yr}$ ) at the Melbu site after transplantation. At Kilpisjärvi, many plants died during the first years after transplantation, but the remaining plants recovered faster than at the oceanic Melbu site, probably because of better soil conditions (O. Skre unpubl.).

\subsection{Temporal changes}

The most obvious temporal change is the high mortality in all provenances at the Kilpisjärvi garden, particularly in the southern and coastal populations, where the survival rates (Fig. 3) dropped from 100\% to $0-40 \%$ during the first $3 \mathrm{yr}$ after transplantation (1992 to 1995). In contrast, survival rates at the Melbu site decreased only to $70-80 \%$ during the same period. After 1995, the mortality seemed to decrease, and at the time of the last control measurement in 2010, the survival rates at Kilpisjärvi had stabilized at 0 to $25 \%$, with the southern populations (GNa and $\mathrm{NBl}$ ) at the lower end of the range and the northern continental populations at the higher end. This was only 20 to $25 \%$ lower than the corresponding survival rates at Melbu in 2010, where there was an almost constant decrease during the whole period. The constructed model (Table 4) also supported those findings, and although the general trend in both gardens seems to be very similar - decrease of survival rate per year was -0.032 in Melbu and -0.031 at the Kilpisjärvi site - the general intercept in the latter is much lower (0.544 vs. 0.865). 
Table 4. Parameters of the linear mixed-model, expressing changes of plant characteristics survival rate (SR), stem base diameter $(D)$ and total height $(H)$, due to time (Year of life) and provenance for the old (top) and new generation (bottom) of plants. The intercept estimates mean value for the Abisko (SAb) provenance. Light shading corresponds to $\mathrm{p}$-value parameters significant at $\alpha=0.05$ and dark shading at $\alpha=0.01$. The predicted general trend value of dependent variable $(D$ $H$, SR) for a particular year of life can be obtained by adding the intercept, estimate for provenance, and mean change per year multiplied by number of years. Values of $\sigma^{2}$ express variation not explained by the model, while $\tau 00$ values express variation explained by each level of nested group (Plants-Replicants-Provenances). $\mathrm{N}$ describes the number of groups distinguished at each level and pseudo- $\mathrm{R}^{2}$ is an equivalent of ratio of variation explained by the model to unexplained variation left, and expresses overall goodness of model fit

\begin{tabular}{|c|c|c|c|c|c|c|}
\hline Variable & SR & $D$ & $H$ & SR & $D$ & $H$ \\
\hline Garden & \multirow{2}{*}{\multicolumn{3}{|c|}{$\longrightarrow$ Melbu }} & \multirow{2}{*}{\multicolumn{3}{|c|}{ Kilpisjärvi }} \\
\hline Fixed parts & & & & & & \\
\hline Intercept-Abisko (SAb) & 0.865 & 4.70 & 25.742 & 0.544 & 5.13 & 38.91 \\
\hline \multicolumn{7}{|l|}{ Provenance } \\
\hline Blefjell (NBl) & -0.035 & -1.32 & -7.528 & -0.169 & $-3.47-$ & -37.36 \\
\hline Hafnarskogur (IHa) & 0.087 & 0.43 & 5.366 & -0.143 & $-1.25-$ & -35.57 \\
\hline Hammerfest (NHa) & 0.066 & 0.75 & 9.748 & 0.039 & 0.20 & -1.41 \\
\hline Kevo280 (FJ) & 0.074 & -0.04 & 3.395 & 0.124 & 0.15 & 2.65 \\
\hline Kevo95 (FK) & 0.084 & -0.60 & -0.250 & -0.017 & 0.00 & -8.42 \\
\hline Kilpisjärvi (FKi) & 0.089 & 0.11 & 2.519 & 0.107 & -0.09 & 4.50 \\
\hline Melbu (NMe) & 0.079 & -0.93 & -3.637 & -0.100 & $-0.60-$ & -26.47 \\
\hline Narssarssuaq (GNa) & 0.006 & -1.10 & -6.762 & -0.184 & $-4.63-$ & -42.45 \\
\hline Utsjoki (FU) & 0.067 & 0.32 & 3.044 & & & \\
\hline Year of life & -0.032 & 0.13 & 0.486 & -0.031 & 0.34 & 2.45 \\
\hline \multicolumn{7}{|l|}{ Random parts } \\
\hline$\sigma^{2}$ & 0.051 & 1.239 & 60.703 & 0.14 & $1.37 \quad 1$ & 156.54 \\
\hline$\tau_{00, \text { Plant:(Replicant:Provenance) }}$ & 0.069 & 2.6391 & 177.108 & 0.03 & 1.463 & 309.42 \\
\hline$\tau_{00, \text { Replicant:Provenance }}$ & 0.002 & 0.459 & 20.285 & 0.01 & 0.32 & 46.13 \\
\hline$\tau_{00, \text { Provenance }}$ & 0 & 0 & 0 & 0.00 & 0.00 & 0.00 \\
\hline $\mathrm{N}_{\text {Plant:(Replicant:Provenance) }}$ & 1500 & 1394 & 1283 & 1350 & 526 & 519 \\
\hline $\mathrm{N}_{\text {Replicant:Provenance }}$ & 60 & 60 & 60 & 54 & 50 & 50 \\
\hline $\mathrm{N}_{\text {Provenance }}$ & 10 & 10 & 10 & 9 & 9 & 9 \\
\hline Pseudo-R $^{2}$ & 0.802 & 0.901 & 0.895 & 0.433 & 0.951 & 0.914 \\
\hline Garden & \multirow{2}{*}{\multicolumn{3}{|c|}{$\longrightarrow$ Vardø }} & \multirow{2}{*}{\multicolumn{3}{|c|}{ —Kilpisjärvi- }} \\
\hline Fixed Parts & & & & & & \\
\hline Intercept-Abisko (SAb) & 1.004 & 7.57 & 27.12 & 1.045 & 3.38 & 52.00 \\
\hline \multicolumn{7}{|l|}{ Provenance } \\
\hline Blefjell (NBl) & -0.030 & -0.05 & -2.41 & -0.165 & 0.86 & -4.34 \\
\hline Hafnarskogur (IHa) & 0.000 & 1.40 & 1.23 & -0.025 & 0.55 & -2.90 \\
\hline Hammerfest (NHa) & 0.001 & 1.25 & 1.61 & -0.015 & 1.38 & -2.40 \\
\hline Kevo95 (FK) & -0.005 & -0.79 & -9.89 & -0.022 & 0.87 & 4.62 \\
\hline Kilpisjärvi (FKi) & -0.012 & 0.40 & -3.11 & 0.012 & 0.76 & 3.62 \\
\hline Melbu (NMe) & 0.026 & 1.38 & -3.99 & -0.028 & 0.67 & 1.70 \\
\hline Narssarssuaq (GNa) & 0.000 & 0.30 & 0.52 & -0.175 & 0.22 & -1.44 \\
\hline Year of life & -0.060 & 0.26 & 1.43 & -0.046 & 0.73 & 0.68 \\
\hline \multicolumn{7}{|l|}{ Random parts } \\
\hline$\sigma^{2}$ & 0.05 & 1.35 & 38.30 & 0.05 & 2.87 & 93.30 \\
\hline$\tau_{00, \text { Plant:(Replicant:Provenance) }}$ & 0.00 & $21.24 \quad 6$ & 603.21 & 0.00 & 0.6111 & 127.04 \\
\hline$\tau_{00, \text { Replicant:Provenance }}$ & 0.00 & 0.852 & 290.49 & 0.00 & 4.013 & 309.77 \\
\hline$\tau_{00, \text { Provenance }}$ & 0.00 & 0.19 & 0.00 & 0.00 & 0.00 & 16.39 \\
\hline $\mathrm{N}_{\text {Plant:(Replicant:Provenance) }}$ & 800 & 435 & 438 & 800 & 471 & 498 \\
\hline $\mathrm{N}_{\text {Replicant:Provenance }}$ & 40 & 40 & 40 & 40 & 39 & 39 \\
\hline $\mathrm{N}_{\text {Provenance }}$ & 8 & 8 & 8 & 8 & 8 & 8 \\
\hline Pseudo-R ${ }^{2}$ & 0.846 & 0.946 & 0.951 & 0.820 & 0.810 & 0.861 \\
\hline
\end{tabular}

Figs. 4 \& 5 show that the lower growth rates and high mortality at the Kilpisjärvi site seem to have been stronger during the first years after transplantation than during the period from 1997 to 2010. This is partly due to spring frost damage, leading to dieback of annual shoots and whole stems, followed by formation of new stems. There seems to have been a strong selection caused by freezing stress, particularly in the non-adapted provenances (Taulavuori et al. 2004, Skre et al. 2008). This may be related to higher frost sensitivity in young plants and seedlings, due to earlier budbreak, than in adult trees (Vitasse et al. 2014b). The transplantation shock and strong selection pressure may also be seen when looking at the temporal changes in total height growth (Fig. 5) and, to a lesser extent, stem base diameter (Fig. 4) in all provenances. In fact, there is a negative growth in total height, or dieback of annual shoots, at Melbu during the first 3 yr after transplantation (Fig. 5), followed by a slow recovery as a result of new root formation and growth (cf. Table 4). A similar development was probably taking place at Kilpisjärvi, as the height increase from 1997 to 2010 is of the same order as at the Melbu site. There was also a slight negative growth in the stem diameter after transplantation that may be due to loss of primary stems and formation of new stems from the roots. The stem diameter measurements were then continued on these new stems, resulting in negative diameter growth caused by the discontinuity (J. Nilsen pers. comm.).

At the Melbu site, the plants from Kevo showed the highest survival rates, while plants from Hammerfest showed the strongest diameter growth (Figs. 3 \& 4). On the other hand, the Kilpisjärvi plants were most successful at Kilpisjärvi (Fig. 3). In both gardens, however, the south- 


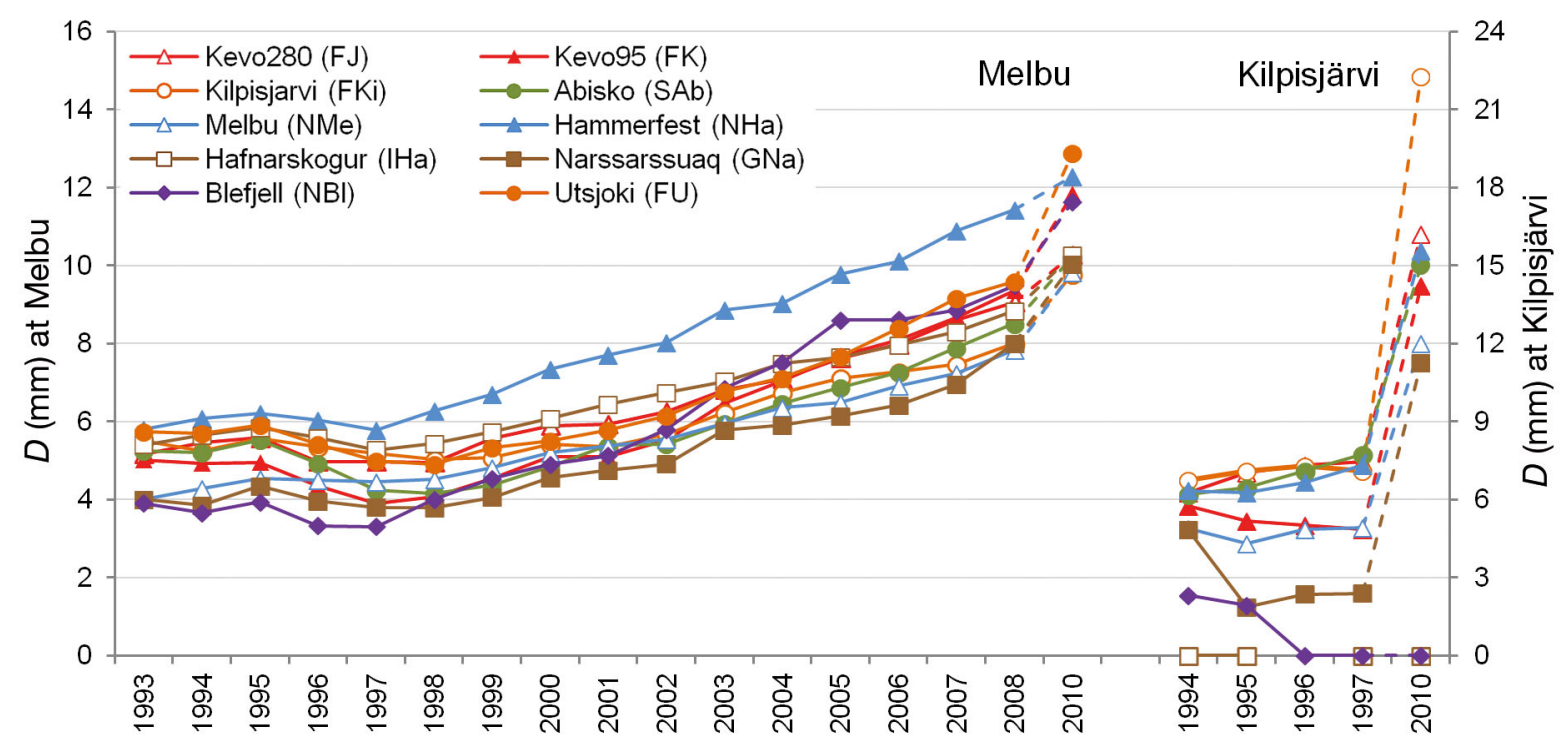

Fig. 4. Stem base diameter $(D)$ for tested provenances of old generations at Melbu (left) and Kilpisjärvi (right) gardens as a function of time since 1992

ern populations (GNa and NBl) had the lowest survival rates.

Comparing the height and diameter growth (Figs. 4 \& 5) with the survival rates in Fig. 3, it may be concluded that there also seems to have been a strong decline in survival rates after 1997 at Kilpisjärvi due to climatic stress (Tables $1 \& 2$ ) and insect attacks (R. Partanen pers. comm.). However, the surviving plants seem to have recovered and reached very similar stem diameters and total heights in 2010 to the corresponding plants at Melbu.
Studies on plant growth and survival after the combined climate and insect damage in the Kilpisjärvi garden during 1994 to 1997 (Figs. 3, 4 \& 5) show that only a few plants from the 3 southernmost populations survived, presumably as a latitudinal effect where plants were subjected to late autumn frost. This latitudinal effect is seen more clearly in Fig. 2, where mean values with $95 \%$ CI are shown for the old set of plants at Melbu and Kilpisjärvi. The 2 southernmost populations (NB and GNa) were both less successful in terms of survival rates, height

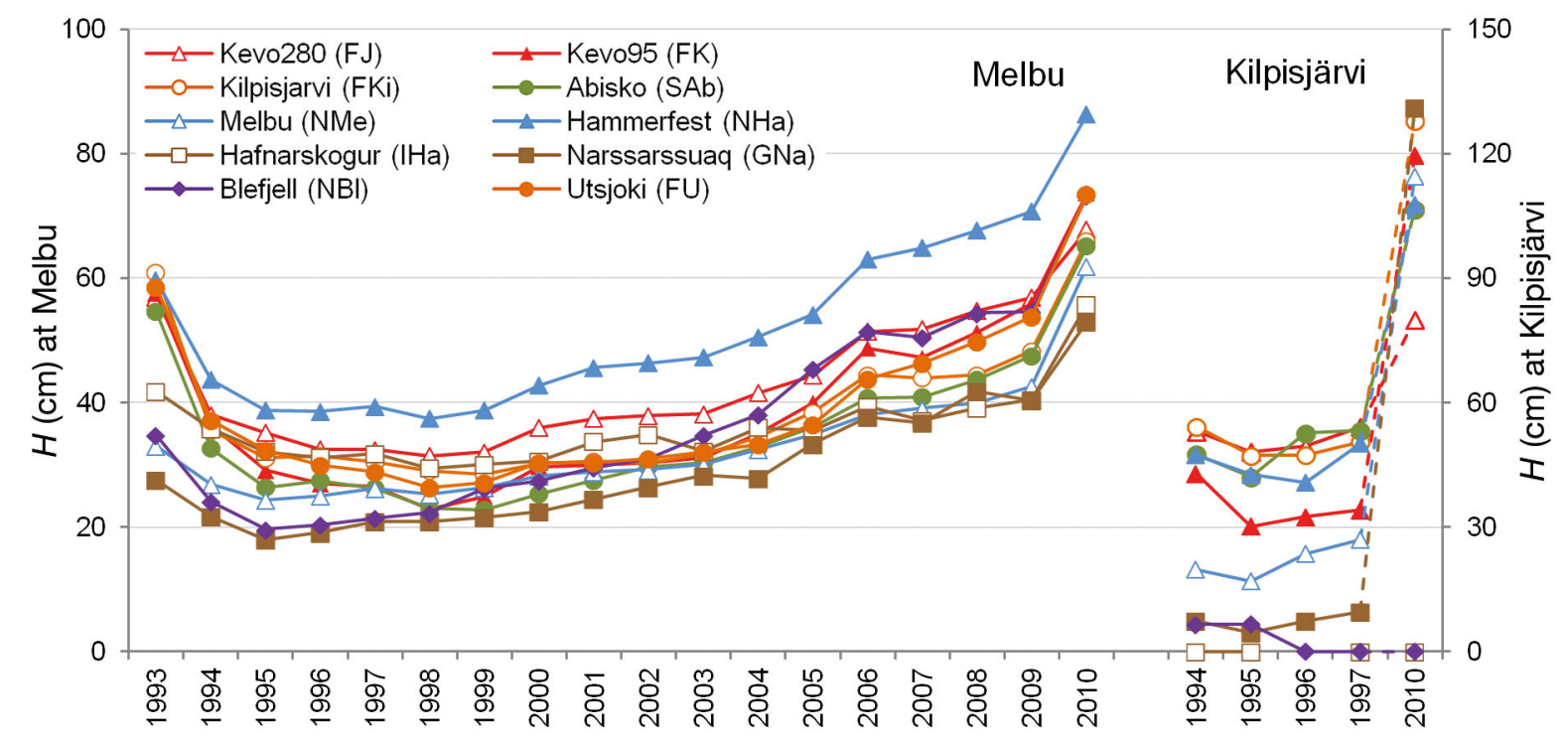

Fig. 5. Total height $(H)$ for tested provenances of old generations at Melbu (left) and Kilpisjärvi (right) gardens as a function of time since 1992 
growth and diameter growth than their northern and continental relatives, and in addition, the less southern but oceanic populations from Iceland (IHa) and Melbu (NMe) were also less successful.

\subsection{Supplementary transplantation}

The survival rates during 2010 to 2014 in the second set of transplanted plants at Vardø and Kilpisjärvi (2002) are shown in Figs. 2 \& 6. At the Kilpisjärvi site, there was a strong latitudinal effect (Fig. 2), where the 3 southernmost populations ( $\mathrm{NBl}, \mathrm{GNa}$ and IHa) were less successful than their northern relatives, but also a certain effect of different oceanity, as the Melbu plants (NMe) were less successful than their continental relatives (FK, FKi and SAb). These results confirmed earlier results on the old dataset from 1992 (see Fig. 2). At the Vardø site, the oceanic provenances were relatively more successful than at Kilpisjärvi, compared with the 3 continental provenances. The northern oceanic plants from Hammerfest (NHa) were the most successful in terms of survival rates at both sites (Fig. 2). Measurements of total living height (Fig. A1) partly confirmed the results of the survival rates, but with generally much lower growth rates in the plants growing at the Vardø site than at the Kilpisjärvi site, in agreement with the differences in summer temperature (Table 1).

However, a clear difference was found in survival rates at Vardø between the 2 different parts of the site (Table A1), illustrating the effect of different snow cover and growing season (cf. Holtmeier \& Broll 2005). In this respect, the 3 continental populations (FK, FKi and SAb) seemed to be most sensitive. Negative height increments owing to dieback were found in all populations at the 4 cold and wet plots (O. Skre unpubl.). In terms of survival rates and height increment, the warm and dry plot at the Vardø site was similar to the Kilpisjärvi site (Fig. 6). It is interesting to notice that plants from Iceland (IHa) showed relatively high survival rates in spite of its southern origin (cf. Table 1). This adaptation may be partly climatic (Myking 1999), but also genetic as a result of inbreeding with Betula nana (AnamthawatJonsson et al. 1993, Thórsson et al. 2001) followed by sheep grazing (cf. Bløndal 1993). Further, results from Swedish studies on insect outbreaks (Tenow et al. 2005) indicate that polycormic birch with a high degree of inbreeding with $B$. nana also is more resistant than monocormic birch, simply because of its ability to rejuvenate after damage (cf. Wielgolaski 2005)

The low number of measurements associated with huge within-site variations at the Vardø site was the main reason why no significant differences were found between provenances there. At the Kilpisjärvi site, the 2 southern and oceanic provenances (NB and GNa) were less successful than the others (Table 4), probably as a latitudinal effect (cf. Myking \& Heide 1995, Skre et al. 2005). The most successful plants at the warm part of the Vardø site in terms of growth increment (Fig. 6) were those from the northern oceanic populations (e.g. NHa, NMe and IHa).

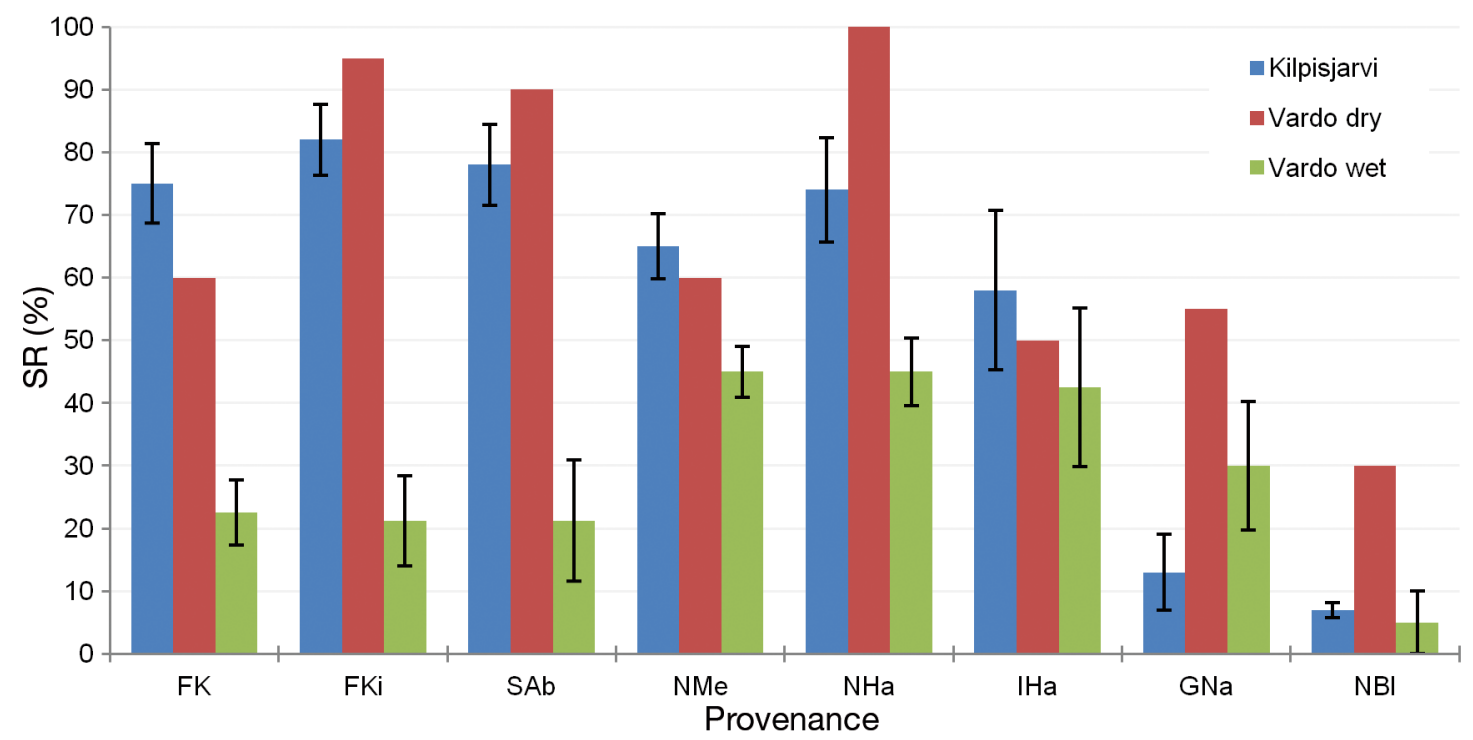

Fig. 6. Mean SR (\%) with $95 \% \mathrm{CI} \pm 2 \mathrm{SE}$ in plants at Kilpisjärvi in 2002 and the wet-cold and dry-warm plot at the Vardø site in 2010 to 2014. The dry-warm plot at Vardø is only shown with its mean values 
This is in accordance with e.g. Myking (1999), who found higher frost resistance in oceanic birch provenances than in continental relatives, probably as a result of adaptation to a longer spring transition period (cf. Taulavuori et al. 2004, Skre et al. 2008).

The present study showed that the Kilpisjärvi site was subjected to at least 2 severe insect attacks, probably by Epirrita autumnata (1995 and 2013), but there was no indication of similar damage at the 2 other sites (Melbu and Vardø), although Melbu is within the potential area of Operophtera brumata (Jepsen et al. 2008). Vardø is still well outside the area, but may be included if the present climate change continues. It may be noted that because Melbu is located $50 \mathrm{~m}$ below the actual treeline, the plants may be in better shape than if they were located at the treeline, and are therefore able to produce more defence substances against insect attacks than the climatically more stressed plants at Kilpisjärvi, close to the treeline (cf. Haukioja et al. 1988, Neuvonen et al. 2005).

\section{CONCLUSIONS}

Returning to the initial questions in the introduction, the present results indicate the following:

(1) Climate change with milder winters and a longer growing season, as well as increasing precipitation, may favour mountain birch plants adapted to an oceanic climate, which are less sensitive to frost and insect damage than continental populations. This strongly suggests that mountain birch would be a good indicator for such changes in the future. The survival rates and growth responses in birch seedlings transplanted to the oceanic site at Melbu and the continental site at Kilpisjärvi varied according to the origin of the seed populations. Consequently, northern continental populations were more successful than their southern oceanic relatives at the Kilpisjärvi site. Northern oceanic populations were superior to southern and continental populations at the oceanic Melbu site, but because this site is located $50 \mathrm{~m}$ below treeline, the conclusions are less significant than at Kilpisjärvi. As expected, the various birch provenances seem to be best adapted to survive and grow in the climate of their origin. However, transplantation to a different climate makes the plants less adapted, but continental provenances seem to suffer more when transplanted to a coastal site (e.g. Vardø) than oceanic provenances when transplanted to a continental site (Kilpisjärvi). In the future, when a warmer climate is expected, this would favour plants that are already adapted to a coastal climate, while continental plants would be more restricted to inland areas. Plants with high demands for dormancy breaking (cf. Myking \& Heide 1995), i.e. southern and oceanic provenances, would have an advantage (Vitasse et al. 2014a) as spring frosts caused by premature dehardening would also be more common (cf. Myking 1999).

(2) The present results seem to indicate that climate is an important driver of change (cf. Körner \& Paulsen 2004), although land-use change such as overgrazing by reindeer and abandonment of farmland may be more important in the short run (Bryn 2008, Aune et al. 2011, Callaghan et al. 2013). The frequent insect attacks by geometrid moths are also related to climate change. Increased reindeer grazing as well as insect attacks would be expected to slow down treeline advance as stated by Virtanen \& Neuvonen (1999), Jepsen et al. (2008) and Callaghan et al. (2013), while reduced reindeer grazing would enhance treeline advance (Neuvonen et al. 1999). The present study also indicated that large differences in survival and growth responses may occur locally, as shown in the Arctic Vardø transplant garden. Different snow and temperature conditions are the main selective factors, and the northern Hammerfest population (NHa) seemed to be most successful at this site. Finally, birch plants growing close to the treeline seem to be subjected to frequent frost damage, causing dieback of annual shoots and negative height increment.

(3) Future predictions (ACIA 2004) for northern areas indicate that a continued temperature increase by up to $2^{\circ} \mathrm{C}$ in the next 50 years, and a more oceanic climate along the coast of northern Scandinavia, is associated with increased risk of insect attacks (Jepsen et al. 2008). Polycormic birch with a high degree of inbreeding with $B$. nana would then have an advantage (Nilsen \& Wielgolaski 2001). Similarly, oceanic birch provenances $(\mathrm{IH}, \mathrm{NMe}$ and $\mathrm{NHa}$ ) would be expected to expand at the expense of continental relatives (FKi, FK, Sab) because they are more adapted to spring frosts (e.g. Taulavuori et al. 2004, Skre et al. 2008). Similar relationships may be used to predict future changes at the species level.

Acknowledgements. Jarle Nilsen is acknowledged for his annual observations in the transplant garden at Melbu, Norway. The study was carried out as part of COST Action ES1203 'Enhancing the resilience capacity of SENSitive mountain FORest ecosystems under environmental change' (SENSFOR). 


\section{LITERATURE CITED}

ACIA (2004) Impacts of a warming arctic climate. Arctic Climate Impact Assessment (ACIA) Overview Report. Cambridge University Press, New York, NY

Anamthawat-Jonsson K, Heslop-Harrison JS, Tomasson T (1993) Genetics, cytogenetics and molecular genetics of Icelandic birch: implications for breeding and reforestation in cold climates. In: Alden J, Mastrantonio JL, Ødum $\mathrm{S}$ (eds) Forest development in cold climates. Plenum Press, New York, NY, p 357-368

Aune S, Hofgaard A, Söderström L (2011) Contrasting climate and land-use driven tree encroachment patterns of subarctic tundra in northern Norway and the Kola Peninsula. Can J Res 41:437-449

Bløndal S (1993) Socioeconomic importance of forests in Iceland. In: Alden J, Mastrantonio JL, Ødum S (eds) Forest Development in cold climates. Plenum Press, New York, NY, p 1-14

Bryn A (2008) Recent forest limit changes in southeast Norway: effects of climate change on regrowth after abandoned utilization? Nor Geogr Tidsskr 62:251-270

Bryn A, Daugstad K (2001) Summer farming in the mountain birch forest. In: Wielgolaski FE (ed) Nordic mountain birch ecosystems. Parthenon Publishing, New York, NY, p 307-315

* Cairns DM, Lafon C, Moen J, Young A (2007) Influence of animal activity on treeline position and pattern: implications for treeline responses to climate change. Phys Geogr 28:419-433

Callaghan TV, Jonasson C, Thierfelder T, Yang Z and others (2013) Ecosystem change and stability over multiple decades in the Swedish subarctic: complex processes and multiple drivers. Philos Trans R Soc Lond B 368: 20120488

Dalen L, Hofgaard A (2005) Differential regional treeline dynamics in the Scandes mountains. Arct Antarct Alp Res 37:284-296

de Wit HA, Bryn A, Hofgaard A, Karstensen J, Kvalevåg MM, Peters G (2014) Climate warming feedback from mountain birch forest expansion: reduced albedo dominates carbon uptake. Glob Change Biol 20:2344-2355

Gamache I, Payette S (2005) Latitudinal response of subarctic tree lines to recent climate change in eastern Canada. J Biogeogr 32:849-862

Gehrig-Fasel J, Guisan A, Zimmermann NE (2007) Tree-line shifts in the Swiss Alps: climate change or land abandonment? J Veg Sci 18:571-582

Haukioja E, Neuvonen S, Hanhimäki S, Niemelä P (1988) The autumnal moth in Fennoscandia. In: Berryman AA (ed) Dynamics of forest insect populations, patterns, causes, implications. Plenum Press, New York, NY, p 163-178

Heide OM (1993) Daylength and thermal time responses of budburst during dormancy release in some northern deciduous trees. Physiol Plant 88:531-540

Holtmeier FK (2007) Mountain timberlines: ecology, patchiness and dynamics. Springer, Berlin

Holtmeier FK, Broll G (2005) Sensitivity and response of Northern Hemisphere altitudinal and polar treelines to environmental change at landscape and local scales. Glob Ecol Biogeogr 14:395-410

Jepsen JU, Hagen SB, Ims RA, Yoccoz NG (2008) Climate change and outbreaks of the geometrids Operophtera brumata and Epirrita autumnata in subarctic birch forests: evidence of a recent outbreak range expansion. J Anim Ecol 77:257-264

Jepsen JU, Hagen SB, Høgda KA, Ims RA, Karlsen SR, Tømmervik H, Yoccoz NG (2009) Monitoring the spatio-temporal dynamics of geometrid moth outbreaks in birch forests using MODIS-NDVI data. Remote Sens Environ 113:1939-1947

Jepsen JU, Biuw M, Ims RA, Kapari L, Schott T, Vindstad OPL, Hagen SB (2013) Ecosystem impacts of a range expanding forest defoliator at the forest-tundra ecotone. Ecosystems 16:561-575

Juntunen V, Neuvonen S (2006) Natural regeneration of Scots pine and Norway spruce close to the timberline in northern Finland. Silva Fenn 40:443-458

Karlsson PS, Nordell KO (1996) Effects of soil temperature on nitrogen economy and growth of mountain birch near its presumed low temperature distribution limit. Ecoscience 3:183-189

Karlsson PS, Weih M (2003) Long-term patterns of leaf, shoot and wood production after insect herbivory in the mountain birch. Funct Ecol 17:841-850

KKörner C, Paulsen J (2004) A world-wide study of highaltitude treeline temperatures. J Biogeogr 31:713-732

Kullman L (1998) Tree-limits and montane forests in the Swedish Scandes: sensitive biomonitors of climate change and variability. Ambio 27:312-321

Kuznetsova A, Brockhoff KA, Christensen RHJ (2016) lmerTest: tests in linear mixed effects models. R package version 2.0-30. Available at https://CRAN.R-project.org/ package=lmerTest

Larsen JB (1976) Untersuchungen über die Frostempfindlichkeit von Douglasienherkünften und über den Einfluss der Nährstoffversorgung auf die Frostresistenz der Douglasie. Forst Holz Wirtsch 31:299-302

* Lehtonen J, Heikkinen RK (1995) On the recovery of mountain birch after Epirrita damage in Finnish Lapland, with particular emphasis on reindeer grazing. Ecoscience 2: 349-356

* Leinonen I (1996) A simulation model for the annual frost hardiness and freeze damage of Scots pine. Ann Bot (Lond) 78:687-693

Lüdecke D (2016) sjPlot: data visualization for statistics in social science. R package version 1.9.4. Available at http: //CRAN.R-project.org/package $=$ sjPlot

Marc J, Mazerolle A (2016) AICcmodavg: model selection and multimodel inference based on (Q)AIC(c). R package version 2.0-4.0. Available at http://CRAN.Rproject.org/package=AICcmodavg

Myking T (1999) Winter dormancy release and budburst in Betula pendula Roth. and B. pubescens Ehrh. ecotypes. Phyton (Horn) 39:139-146

Myking T, Heide OM (1995) Dormancy release and chilling requirements of buds of latitudinal ecotypes of Betula pendula and B. pubescens. Tree Physiol 15:697-704

Neuvonen S, Niemelä P, Virtanen T (1999) Climate change and insect outbreaks in boreal forests: the role of winter temperatures. Ecol Bull 47:63-67

Neuvonen S, Bylund H, Tømmervik H (2005) Forest defoliation risks in birch forest by insects under different climate and land use scenarios in northern Europe. In: Wielgolaski FE (ed) Plant ecology, herbivory and human impact in Nordic mountain birch forests. SpringerVerlag, Berlin, p 125-138

Nilsen J, Wielgolaski FE (2001) Effects of fertilization and watering on morphology in young mountain birch plants 
of different provenances - a pilot study. In: Wielgolaski FE (ed) Nordic mountain birch ecosystems. UNESCO, Paris and Parthenon, New York, NY, p 71-76

Ovaska JA, Nilsen J, Wielgolaski FE, Kauhanen H and others (2005) Phenology and performance of mountain birch provenances in transplant gardens: latitudinal, altitudinal and oceanity-continentality gradients. In: Wielgolaski FE (ed) Plant ecology, herbivory and human impact in Nordic mountain birch forests. Springer-Verlag, Berlin, p 99-115

Payette S, Eronen M, Jasinski JJP (2002) The circumboreal tundra-taiga interface: Late Pleistocene changes. Ambio $12: 15-22$

R Core Team (2015) R: a language and environment for statistical computing. R Foundation for Statistical Computing, Vienna. Available at https://www.R-project.org/

Scott PA, Hansell IRC, Ericsson WR (1993) Influence of wind and snow on northern treeline environments at Churchill, Manitoba, Canada. Arctic 46:316-323

Skre O, Baxter R, Crawford RMM, Callaghan TV, Fedorkov A (2002) How will the tundra-taiga interface respond to climate change? Ambio 12:37-46

Skre O, Nilsen J, Næss M, Igeland B, Taulavuori K, Taulavuori E, Laine K (2005) Effects of temperature changes on survival and growth in mountain birch populations. In: Wielgolaski FE (ed) Plant ecology, herbivory and human impact in Nordic mountain birch forests. Springer-Verlag, Berlin, p 87-98

Skre O, Taulavuori K, Taulavuori E, Nilsen J, Igeland B, Laine K (2008) The importance of hardening and winter temperature for growth in mountain birch populations. Environ Exp Bot 62:254-266

Speed JDM, Austrheim G, Hester AJ, Mysterud A (2011) Browsing interacts with climate to determine tree-ring increment. Funct Ecol 25:1018-1023

Sveinbjörnsson B, Hofgaard A, Lloyd A (2002) Natural causes of the tundra-taiga boundary. Ambio 12:23-29

* Taulavuori K, Taulavuori E, Skre O, Nilsen J, Igeland B, Laine K (2004) Dehardening of mountain birch (Betula pubescens ssp. czerepanovii) ecotypes at elevated temperatures. New Phytol 162:427-436

Tenow O, Bylund H, Nilsen AC, Karlsson PS (2005) Longterm influence of herbivores on northern birch forests. In: Wielgolaski FE (ed) Plant ecology, herbivory and human impact in Nordic mountain birch forests. Springer-Verlag, Berlin, p 165-182

* Thórsson AT, Salmela E, Anamthawat-Jonsson K (2001) Morphological, cytogenetic and molecular evidence for introgressive hybridization in birch. J Hered 92:404-408

* Tømmervik H, Johansen B, Tombre I, Thannheiser D, Høgda KA, Gaare E, Wielgolaski FE (2004) Vegetation changes in the Nordic mountain birch forests: the influence of grazing and climate change. Arct Antarct Alp Res 36:323-332

Virtanen T, Neuvonen S (1999) Performance of moth larvae on birch in relation to altitude, climate, host quality and parasitoides. Oecologia 120:92-101

* Vitasse Y, Lenz A, Körner C (2014a) The interaction between freezing tolerance and phenology in temperate, deciduous trees. Front Plant Sci 5:541

*Vitasse Y, Lenz A, Hoch G, Körner C (2014b) Earlier leaf-out rather than difference in freezing resistance puts juvenile trees at greater risk of damage than adult trees. J Ecol 102:981-988

Weih M, Karlsson PS (1999) Growth responses of altitudinal ecotypes of mountain birch to temperature and fertilization. Oecologia 119:16-23

Wielgolaski FE (2005) History and environment of the Nordic mountain birch. In: Wielgolaski FE (ed) Plant ecology, herbivory and human impact in Nordic mountain birch forests. Springer-Verlag, Berlin, p 3-18 


\section{Appendix}

Table A1. Mean dates of budbreak at Replicates I to IV and V in Vardø during the observation years 2010 to 2015, and estimated snow cover in days $(\mathrm{SMD}=$ date of snowmelt, $\mathrm{SFD}=$ date of first snowfall, $\mathrm{SD}=$ duration of snow-free period)

\begin{tabular}{|lcc|}
\hline Year $^{\mathrm{a}}$ & I to IV & $\mathrm{V}$ \\
\hline 2010 & 24.6 & 17.6 \\
2012 & 23.6 & 14.6 \\
2014 & 23.7 & 16.6 \\
2015 & 15.6 & 9.6 \\
& & \\
Mean & 21.6 & 14.6 \\
SMD & 17.5 & 10.5 \\
SFD & 17.10 & 30.10 \\
SD & 155 & 169 \\
\multicolumn{2}{l}{ abservations on budbreak were missing in 2011 and } \\
2013, but were taken in 2015, after the end of the sample \\
period (2014)
\end{tabular}
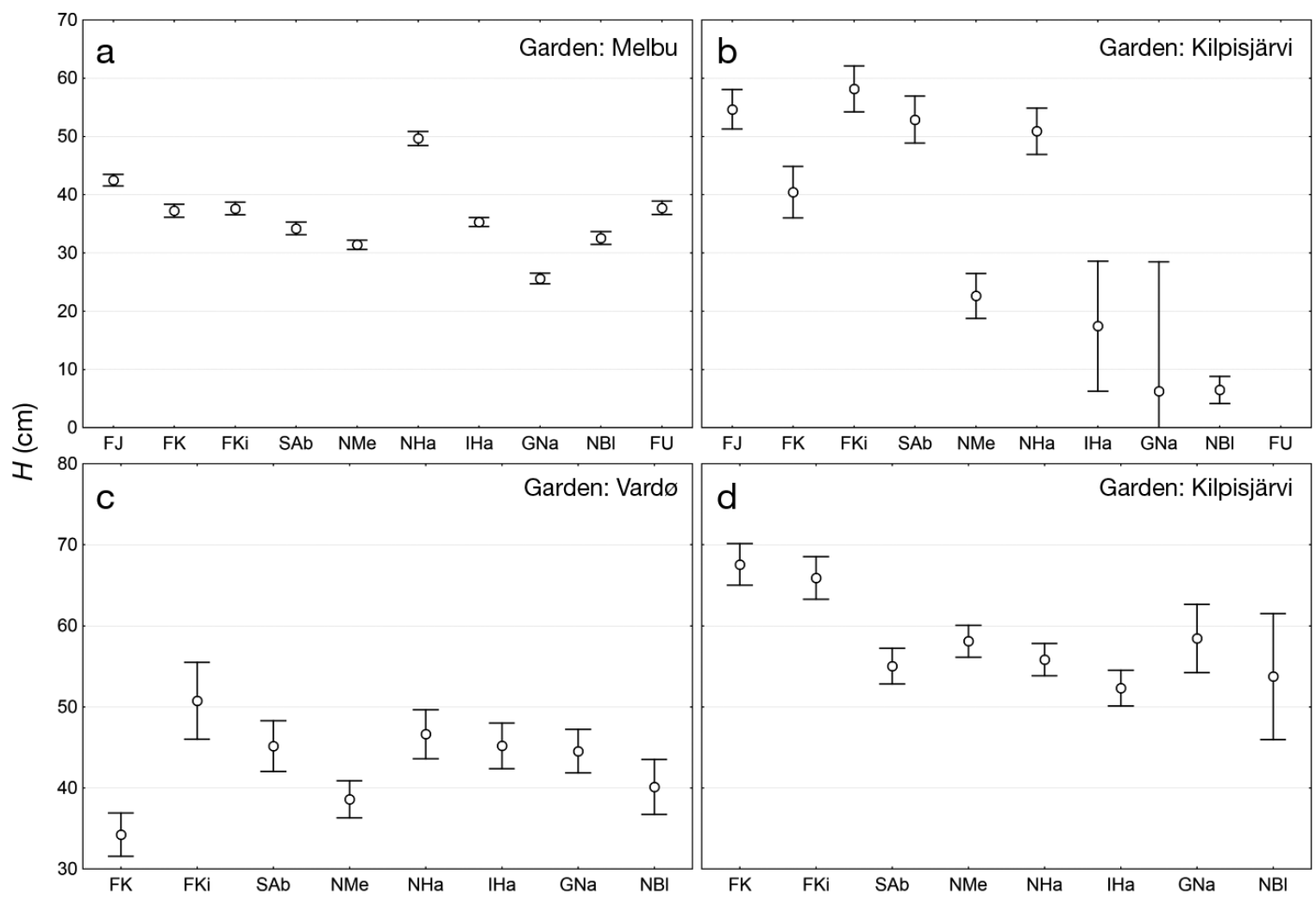

Fig. A1. Mean values of total height $(H)$, with corresponding $95 \%$ CI for tested provenances of $(\mathrm{a}, \mathrm{b})$ old generation of plants at (a) Melbu and (b) Kilpisjärvi and (c,d) new generation of plants at (c) Vardø and (d) Kilpisjärvi 